\title{
I-Business Firms in the Industry 4.0 Global Value Chains
}

\author{
Milena Balanova ${ }^{1, *}$ Oleg Bodiagin ${ }^{1}$ Inga Mezinova ${ }^{1,2}$ Paskal Zhelev $^{3}$
}

\author{
${ }^{1}$ Rostov State University of Economics, Rostov-on-Don 344002, Russia \\ ${ }^{2}$ Don State Technical University, Rostov-on-Don, Russia \\ ${ }^{3}$ University of National and World Economy, Sofia 1700, Bulgaria \\ * Corresponding author: Email: ipd.rsue@gmail.com
}

\begin{abstract}
I-business firms are upraising their capitalization compared to traditional pipeline businesses due to value cocreation with other participants - complementors, supply-side and demand-side users - forming a business ecosystem. The paper discusses the concept of value creation for platform firms and analyzes i-firms' integration in the global value chains under the influence of Industry 4.0. It results in providing the models of contemporary GVCs with i-business firms embedded in them.
\end{abstract}

Keywords: ecosystem, GVC, i-business (platform-based) firms, MNE, value creation

\section{INTRODUCTION}

I-business firms, also widely known as platform-based firms, are becoming the core of the modern global economy. This happens due to their ability to generate value faster than traditional pipeline firms.

Faster and better responding to consumer demand both in B2B and B2C markets is the specific feature of value chains forming under Industry 4.0 pressure which enables establishing win-win relationships among chain actors, thus increasing competitive advantages of all the parties involved.

Our research is aimed on study how value creation happens for i-business firms. We state that the mechanisms which lie in the new models of business, including ecosystem-based platforms, are distinct from the traditional Gereffi's GVC model. We also show that i-business companies owe different legal status in the market depending on whether it is an autonomous business entity introducing a unique, innovative offering to the world and, thus, creating a new market, or it is a unit of a vertically integrated MNE willing to increase its value and become more competitive on the global market.

\section{BACKGROUND}

With the market imbalances on the global market since 2000s digitized companies have moved to forward positions in world rankings like Top-50 most innovative companies by $\mathrm{BCG}$, the Global Unicorn Club by CBInsights, Top 100 ExOs, Top 100 Digital Companies by Forbes, etc. Such a bias to asset light ibusiness firms resulted in a number of analyses of a data-centric business models, especially a platform business model they are actively implementing. Platforms became a subject of research of a number of scholars including M. Van Alstyne, G. Parker \& S. Choudary (2016) [1], M. Jacobides (2019) [2], J. Kim (2015) [3], J.-C. Rochet \& J. Tirole (2003, 2006) [4; 5]. Since platforms operate as part of an ecosystem being its environment favorable for value capture and cocreation there is a number of works by $\mathrm{R}$. Adner (2017) [6], R. Kapoor (2018) [7], M. Jacobides, C. Cennamo, \& A. Gawer (2018) [8], dedicated to the study of the nature of ecosystems. Meanwhile, the mechanism, which underpins the value creation in ibusiness firms, is still at the conceptualization stage in researches. Section 3 describes specific features of this mechanism distinct from the traditional Gereffi's GVC model in detail. Another important issue which is currently insufficiently studied and has no rigid framework of how the model the global value chain of i-business firms or traditional linear MNEs using platform business models should be like. There have been studies of the GVC being transformed under the influence of business digitalization and platformization by the UNCTAD group $(2018,2019)$ $[9,10]$. An attempt to show the scenarios of how digital platforms are engaged in the modern GVCs will be exposed below in Section 4.

To highlight the crucial subject of scientific debates, it is worth providing a definition to i-business firms. Ibusiness, or platform-based, firms are business entities that either fully use a platform business model (advanced i-business firm) or apply a platform business model and a platform strategy as a supplementary way to increase its income and compete among other firms globally (fractional ibusiness firm). Platform strategy proved its efficiency in delivering innovations in a wide variety of industries [3]. Eight out of top ten companies in "Best Global Brands 2018 Rankings" by Interbrand have 
fully or partly adopted a platform business model (Table 1) [11].

Table 1 Platforms by enterprise type

\begin{tabular}{|c|c|c|c|c|c|}
\hline Structure & $\begin{array}{c}\text { Hierarchical } \\
\text { Organization } \\
+ \\
\text { Physical } \\
\text { Assets }\end{array}$ & $\begin{array}{l}\text { Platform } \\
\text { ecosystem }\end{array}$ & Companies & Platform & $\begin{array}{c}\text { Position in } \\
\text { Interbrand } \\
2018\end{array}$ \\
\hline Asset Heavy & & 0 & $\begin{array}{c}\text { Mercedes- } \\
\text { Benz } \\
\\
\text { Samsung } \\
\text { Toyota } \\
\end{array}$ & $\begin{array}{l}\text { Moovel } \\
\text { Tizen } \\
\text { Linux } \\
\end{array}$ & $\begin{array}{l}8 \\
6 \\
7\end{array}$ \\
\hline Mixed & & & $\begin{array}{c}\text { Amazon } \\
\text { Apple } \\
\text { Microsoft }\end{array}$ & $\begin{array}{l}\text { App Store } \\
\text { App Store } \\
\text { Windows }\end{array}$ & $\begin{array}{l}3 \\
1 \\
4 \\
\end{array}$ \\
\hline Asset Light & & & $\begin{array}{c}\text { Facebook } \\
\text { Google }\end{array}$ & $\begin{array}{c}\text { Facebook app } \\
\text { Google Play }\end{array}$ & $\begin{array}{l}9 \\
2\end{array}$ \\
\hline
\end{tabular}

A platform business model is likely to involve a transaction occurring in a 'two-sided market ' $[4 ; 5]$ that consists of a component, a rule, and two sides [12], thus creating an ecosystem which enables materialization of value proposition [6]. Ecosystem, along with the i-business firm, includes suppliers, customers, and complementors. Ecosystems allows all the parties become collaborators through co-creation, what makes an ecosystem different from an integrated firm or a market [13].

The value chain concept, presented by Michael Porter back in 1985, is one of the most valued concepts and backbones in economics [14]. It has seriously evolved over time, resulting in diverse definitions from the different strands of debate: world systems theory, firm's theory, systems and supply chain management concepts, international trade theory, international business concepts, etc. [15, 16].

For the purpose of our research we share the approach towards the value chains as a strategic network which are built for the purpose of better responding to consumer demand [17], by establishing win-win relationships among chain actors.

Gary Gereffi's global value chain (GVC) concept [18] is in line with the above mentioned approach, even though it is mostly used in international business field for studying relationships between multinational companies, the "lead firms", and other participants in international value chains (Fig. 1a).

However, technologies of Industry 4.0, as described by Marnix Montanus [19] transform value creation in manufacturing value chains. New technologies boost the role of intangibles (e.g., R\&D, design, software, market research and branding) in income generation, reduce energy consumption, enable more decentralized and flexible production and distribution, etc., thus letting companies capture and co-create value with a world of thousands of partners being members of business ecosystems centralized by a platform(s) (Fig. 1b).

Therefore, understanding the nature of value creation for ibusiness firms and exploring their integration in the global value chains in the context of Industry 4.0 are set as the main objective of the work. The tasks of the paper are as follows: to define the mechanisms lying in the platform business models and determine the roles (an autonomous business entity or a part of the linear MNE) of platforms in the Industry 4.0 global value chains.

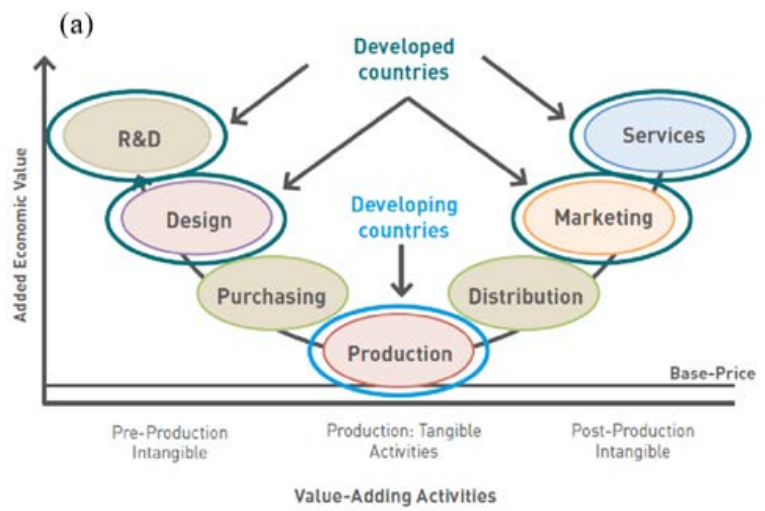

Source: Gereffi \& Fernandez-Stark, 2016 [18].

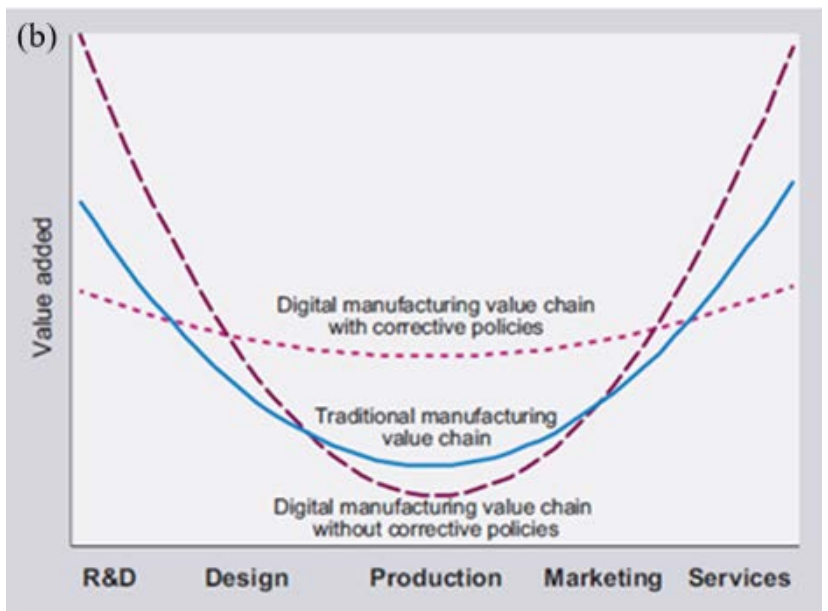

Source: UNCTAD, 2018, 72 [9].

Figure 1 (a) Gereffi's smile curve of high-value activities in GVC, (b) Stylized manufacturing value chain smile curve

\section{TRANSFORMATION OF GEREFFI'S GLOBAL VALUE CHAIN FOR I-BUSINESS FIRMS}

Our first task of the research is to investigate whether ibusiness firms share the same rationale as pipeline firms within traditional Gereffi's GVC model.

Hypothesis 1. Mechanisms which lie in the new models of business, including ecosystem-based platforms, are distinct from the traditional Gereffi's GVC model and include a core offering being an intangible asset, complementary offerings and network effects generated on the basis of the platform. 
The service of core offering, or the key strategic asset, in the platform is "control and use of digitized data to organize and mediate transactions between the various actors in the chain, combined with the capability of expanding the size of such ecosystems in a circular, feedback driven process" [1]. The latter is called 'network effects' - a phenomenon of the platform value increase which depends on the growth of platform users and complementors [11].

GVCs that integrate i-business firms showcase three cases.

i. Ecosystem gives freedom, but this freedom has its established limits [2]. This is an extremely important feature of the ecosystem-based platform. The platform is unique in getting profit from immense minimizing transaction and search costs. Customers neither waste time on searching for complements for their core offering and verifying if the supplier-side provides a high-quality offering to deserve trust in case of the market model nor buy a package offering formed by the system integrator, like in the integrated firm.

ii. Network effects exist. Although network effects also exist in the traditional market and the hierarchically integrated firm, their impacts are different. In ecosystem the network effect emerges from 'transaction 'because transactions in two-sided markets create value by facilitating interactions between the different sides" [3]. While the conventional value chain implies that there exists only direct network effect, in case of ecosystems there are both direct and indirect network effects. Direct effects imply the dependence of the overall value of a product/service on the number of users (the more users are attracted, the higher the value of the product/service is). Indirect (cross-side) network effects entail the dependence on the number of more categories of users indirectly connected via a platform and influencing the platform viability ('the value of the service increases for one user group when a new user of a different user group joins the network '[20].

Although both types of network effects add value to the platform, indirect network effects are more powerful, since they critically influence the exponential growth of platformbased companies with peer-to-peer relationships [20].

iii. Value chains transform under platform pressure. In the conventional Porter's and Gereffi's value chain, producers are located on the left side while consumers are located on the right side, the value flowing unilaterally from the left to the right. Nevertheless, the value chain of platform companies has its structural and relational changes, since the platform business model entails platform owners ' establishing relationships both with producer and consumer groups, which "maximizes the interaction between both aspects (or multi aspects) of mutually different properties of the value chain and thereby create an ecosystem" [12].

Analyzing platform business models in respect to the value chain, Kim (2015) identifies three types of value chains transformation: an external expansion of the value chain, a reverse flow of the value chain, or an integration of the value chain. The results of this study indicate three types of platforms.

1) Supplier type - producer-oriented platform. In the producer-oriented platform, a normal value chain starts from the supply side - producers deliver certain products or services to their consumers through the platform (e.g., eBay's open market, Microsoft Windows, Nintendo). However, there is no reverse flow value chain: these platforms include value creation, but no value co-creation, since supplier type chains are producer-centered. However, both direct and indirect network effects might exist in the producer-oriented platform.

2) Tailor type - consumer-oriented platform. According to Kim (2015), the consumers request products or services from the producers through a platform and then the producers produce and deliver them to the consumers through the platform, therefore, consumers taking the lead in the use of the platform (e.g., Google AdWords, Samsung AdHub, Kickstarter's idea platform). The source of value creation is the customer, generating both value creation and value co-creation together with platform stakeholders (p. 166-167). Both direct and indirect network effects take place in the consumer-oriented platform.

3) Facilitator-type - both-oriented platform. Platform participants (consumers and producers) both produce and consume products and services through the platform (e.g., Facebook, Instagram, YouTube, Yahoo answers platform). Normal and reverse value chains happen simultaneously, making both value creation and value co-creation occur, as well as facilitating both direct and indirect network effects.

\section{HOW I-BUSINESS FIRMS EMBED IN GVCS OF MULTINATIONAL FIRMS}

Another task of the research was to view the status of ibusiness firms engaged in global business and their position in GVCs. It is of note that exploring 2 models of i-business firms' embeddedness in Industry 4.0 GVCs the volume of the added value of each GVC component, activity was not considered. Thus, revisited Gereffi's smile curve with i-business firms embedded there show no curve, which can be an object of further analysis.

Hypothesis 2. Platform companies owe different legal status in the market depending on whether it is an autonomous business entity introducing a unique, innovative offering to the world and, thus, creating a new market, or it is a unit of a vertically integrated MNE willing to increase its value and become more competitive on the global market.

Based on this consideration, there is a proposal to differentiate between two scenarios of platforms' embeddedness into the GVCs of MNEs.

Scenario 1 - Platform companies are full players of the market and own one activity of the value chain, revisiting Gereffi's Smile Curve; MNEs outsource distribution or marketing using platform companies. 
This scenario means that MNEs are platform companies controlling distribution/marketing, i.e. performing as a new market for other sellers of products/services in the ecosystem.

For instance, Alibaba is an enormous marketplace for millions of sellers distributing their offerings through its affiliated entities (Alibaba.com, AliExpress.com, Taobao.com, Tmall, Ele.me). Other activities - R\&D, design, purchasing, production, services, etc. are introduced by the supply side and, thus, the supply side responds for their value creation.

Therefore, platform companies generate new markets and enable sellers to capture additional value on entering this market while the supply side producing offerings outsource platform companies 'activities to capture additional value. MNEs outsource marketing and/or distribution, thus becoming users of the platform company (Fig. 2a).

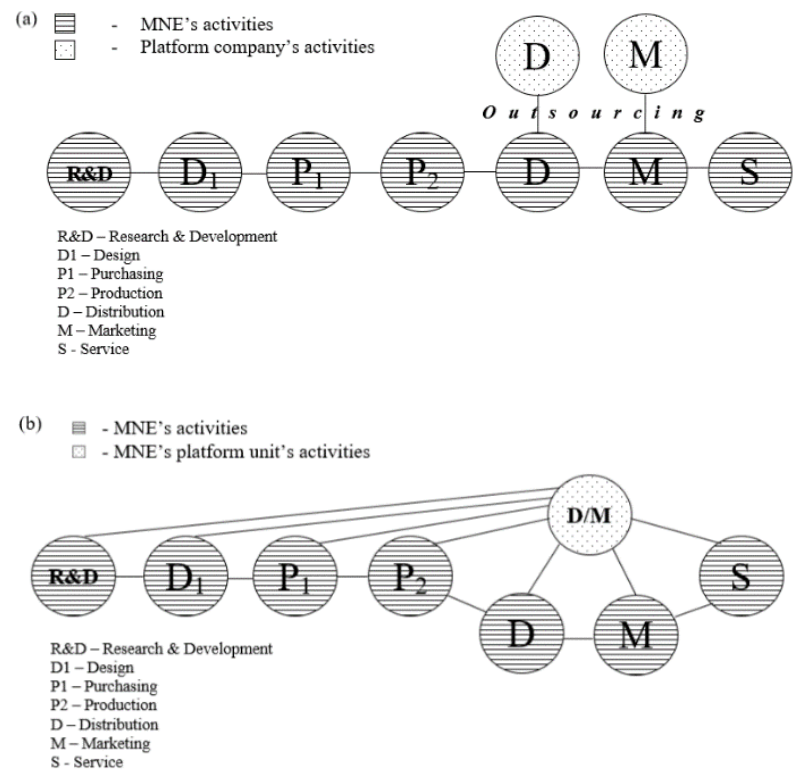

Figure 2 (a) - GVC model of MNEs outsourcing platform companies 'activities, (b) - GVC model of MNEs embedding platform business models

Scenario 2 - MNEs platform business models complement to the value creation of the whole value chain The second scenario bears the idea that linear MNEs embed a platform business model in their already existing GVC. For example, Apple created an Appstore platform itself, and made it a fully engaged unit of the business. MNEs use FDI to launch their platforms, however MNEs ' relationships with platform users (complementors, suppliers and customers) entail the modular governance type (Fig. 2b). What is worth underlining is that a platform is engaged in all stages of product value creation: since the inception of creative ideas and $R \& D$ up to service provided after selling an offering.

\section{CONCLUSION}

I-business firms transmit new approach towards creation of value in global value chains, especially in manufacturing. It is enabled by new technologies of Industry 4.0 that enhance the role of intangibles (e.g., $\mathrm{R} \& \mathrm{D}$, design, market research and branding) in income generation, thus letting companies capture and co-create value while being members of business ecosystems centralized by a platform. These ecosystem-based platforms are distinct from the traditional Gereffi's GVC model and include a relevant degree of freedom for the parties, core offering being an intangible asset, constant development of the platform, complementary offerings and network effects generated on the basis of the platform.

We also showcase three types of value transformation when companies use platform business models: an external expansion of the value chain, a reverse flow of the value chain, or an integration of the value chain.

Hypothesizing on the scenarios of i-business firms' embeddedness in GVCs of multinational firms, two scenarios were formulated. Both of them presuppose the modular governance type. However, MNEs of the first scenario outsource distribution/marketing, becoming themselves users of the platform company. The second scenario MNEs use FDI to launch their platforms, the latter being their embedded business model as a constituent part of the whole entity.

\section{REFERENCES}

[1] M.W. Van Alstyne, G.G. Parker, S.P. Choudary, Pipelines, platforms, and the new rules of strategy, Harvard Business Review. 62 (2016) 54-60.

[2] M.G. Jacobides, Internet of Things 2019. IoT Lab, 2019. Retrieved from https://youtu.be/AmjOlblbjwE

[3] J. Kim, The Platform Business Model and Strategy: A Dynamic Analysis of the Value Chain and Platform Business, Doctor of Science Thesis, Manchester Business School, 2015.

[4] J.-C. Rochet, J. Tirole, Platform Competition in Two-Sided Markets, Journal of the European Economic Association. 1 (2003) 990-1029. DOI: https://doi.org/10.1162/154247603322493212

[5] J.-C. Rochet, J. Tirole, Two-Sided Markets: Where We Stand, Rand Journal of Economics. 37 (3) (2006) 645-66.

[6] R. Adner, Ecosystem as Structure: An Actionable Construct for Strategy, Journal of Management. 43(1) (2017) 39-58. DOI:

https://doi.org/10.1177/0149206316678451 
Models and Ecosystem Roles, Technology Innovation Management Review. 8(3) (2018) 5-15.

[14] M.E. Porter, Competitive advantage: creating and sustaining superior performance. Free Press, 1985.

[15] E. Nang’ole, D. Mithöfer, S. Franzel, Review of guidelines and manuals for value chain analysis for agricultural and forest products, Occasional Paper, 17 (2011).

[16] J. Donovan, S. Franzel, M. Cunha et al., Guides for value chain development: a comparative review / Journal of Agribusiness in Developing and Emerging Economies, 2015. DOI 10.1108/jadee-07-2013-0025

[10] UNCTAD, Digital Economy Report 2019: Value Creation and Capture: Implications for Developing Countries, United Nations Publication, 2019. DOI: https://doi.org/10.18356/c7dc937a-en.

[11] O.V. Bodiagin, M.M. Balanova, Towards the embeddedness of i-business (platform-based) firms in the GVCs of modern MNEs. Proceedings of the 15th International Conference of ASECU “Sustainable Development Goals 2030: Challenges for South and Eastern European Countries and the Black Sea Region”, Sofia: Unwe Publishing Complex. (2019) 355-366.

[12] T. Eisenmann, G. Parker, M. W. Van Alstyne, Strategies for two-sided markets, Harvard Business Review. 84(10) (2006) 92.

[13] H. Ikavalko, P. Turkama, A. Smedlund, Value Creation in the Internet of Things: Mapping Business
[17] J. Hobbs, A. Cooney, M. Fulton, Value Chains in the Agri-Food Sector: What are they? How do they work? Are They for Me?, Department of Agricultural Economics, University of Saskatchewan, Saskatoon, 2000.

[18] G. Gereffi, K. Fernandez-Stark, Global Value Chain Analysis: A Primer, Center on Globalization, Governance \& Competitiveness (2nd ed.). Duke University, 2016.

[19] M. Montanus, Business Models for Industry 4.0: Developing a Framework to Determine and Assess Impacts on Business, Master of Science Thesis, Delft University of Technology, 2016.

[20] N.L. Johnson, Platform vs. Linear: Business Models 101, 2017. Retrieved from https://www.applicoinc.com/blog/platform-vs-linearbusiness-models-101/ 